\title{
Import Trade of Producer Services Helps BRICS Economies Upgrade Manufacturing
}

\author{
Yang Haiyue \\ Economic Institute. Shanghai University \\ Shanghai, China \\ E-mail: 826846765@qq.com
}

\begin{abstract}
BRICS economies are all faced with the challenge of manufacturing industry upgrade. BRICS Economies can upgrade their manufacturing though manufacturing servitization. This paper bases on noncompetitive input-output data during 1995-2011 in the BRICS and use input-output method investigate imported producer services' effects on the manufacturing servitization. The study suggests that China is increasingly dependent on the imported producer services. However, the proportion of imported producer services input in manufacturing is very small, it has very little impact on manufacturing servitization; but the imported producer services have great backward influence on manufacturing industry in BRICS economies. Above all, manufacturing has not taken full use of imported producer services in BRICS economies.
\end{abstract}

Keywords-Manufacturing Servitization; Producer Services; Input-Output Method; BRICS Economies; Import Trade

\section{INTRODUCTION}

The BRICS economies' economy development is soaring during the last two decades. However, under the influence of the international economic environment, the economic growth of some BRICS economies has slowed. Manufacturing servitization is transforming BRICS economies into innovative nations, and value service innovation, and smarter manufacturing.

Combination in industrial chain by manufacturing and producer services, production process remolding needs professional services such as technology, management and innovation. It would be an effective way for BRICS economies to stretch to the high end of value chain and improve the efficiency of manufacturing industry. Industrial upgrading is one of the core problems facing in the development of BRICS economies. BRICS economies need to upgrade their manufacturing through put more producer services to manufacturing. This paper focus on imported producer services, in order to find out whether producer services import trade can help BRICS economies upgrade their manufacturing. This paper uses the noncompetitive input-output data during 1995-2011 in the BRICS. The input-output table comes from WIOD, for we don't have the date of South Africa, we will only investigate Brazil, China, India and Russia.

\section{CURRENT DEVELOPMENT}

This paper first measures the proportion of producer services import trade in service trade to measure the level of the producer services import trade of the BRICS economies.

1. The proportion of producer services import has been increased year by year during 1995 to 2002 in China and India, Brazil. (Table 1.). The proportion of producer services import trade in Service trade increased to more than $75 \%$ in BRICS economies in the year of 2011, China has reached to $75 \%$. In addition to the Russian the proportion of producer services import trade in service trade has been maintained at a high level of $88 \%$, the proportion of producer services import trade in Service trade has been a great increase during 1995-2011 in China, India and Russia, this shows that the import of producer services is in a very important position in the import of service trade in BRICS economies.

2. Around 2003, in China, India and Brazil the import of producer services proportion declined because the import trade of producer services is impacted by the economic crisis.

TABLE I. The Proportion of Imported Producer Services in Service Trade

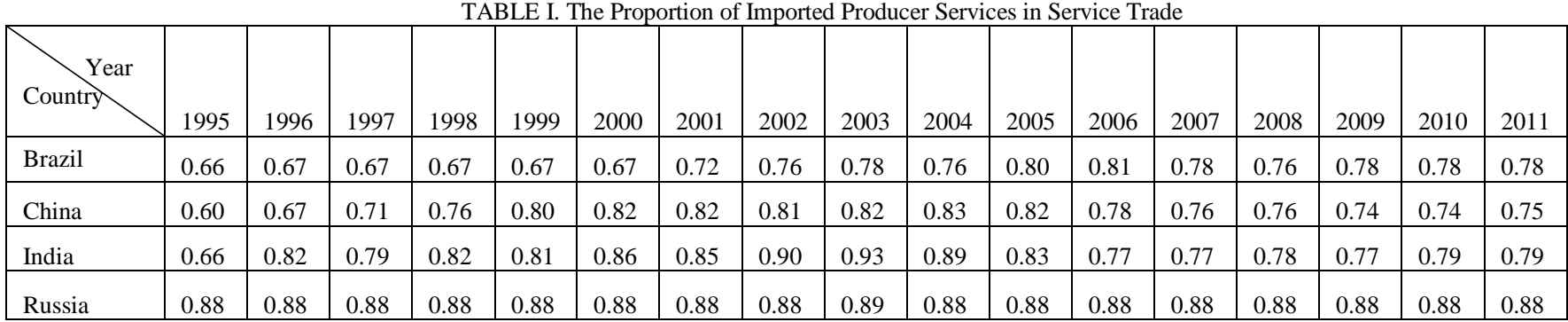

Date source: WIOD input-output table 


\section{A. Intermediate Input}

This paper draws on the research methods of Park in the study of the dependency relationship between the manufacturing and service industry. Park has use intermediate input coefficient to describe the relationship between producer services and manufacturing, the proportion of imported producer services in all intermediate inputs in manufacturing can be described as:

$$
b_{i j}=x_{i j} / m_{j}
$$

Where $\mathrm{i}$ denotes industry of producer services and $\mathrm{j}$ denotes industry of manufacturing. ${ }^{x_{i j}}$ is the number of service occupations and $m_{j}$ is the total number of occupations (service and production occupations). $b_{i j}$ can measure the importance of imported producer services to manufacturing production.
In Fig1. B denotes Brazil; C denotes China; I denotes India; R denotes Russia

1. The imported producer services as intermediate input in manufacturing in the BRICS economies is generally low, and the highest is only $1.32 \%$. In 1995, the number in China is only $0.3 \%$.

2. The number in China and Brazil keeps increase during 1995-2011, but slowdown in 2008.It may influence by the economic crisis.

3. India: The imported producer services in the inputs of manufacturing is the highest in four countries, it is $1.32 \%$ in 2006 , but decrease to $0.82 \%$ in 2010 .

4. Russia: The number keeps increase during 19951999, but turn reduce from 2000, it is the lowest in four countries in 2010 , only $0.62 \%$.

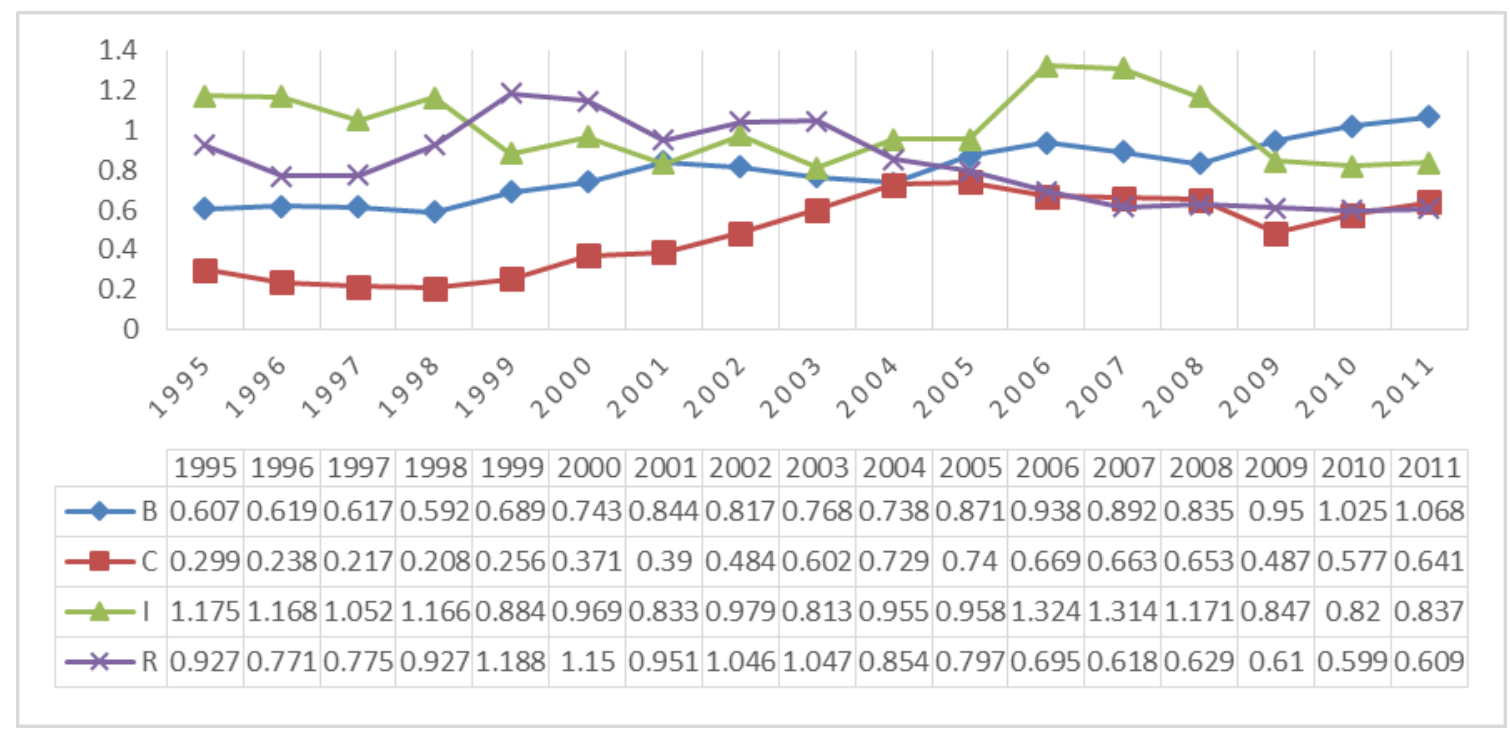

Figure 1. The Intermediate Input of Imported Producer Services in Manufacturing. Unit:\%

\section{B. Forward Effects}

Forward effects are the proportion of producer services purchased from abroad by the manufacturing sector in the manufacturing output. It can be described as:

$$
d_{i j}=y_{i j} / y_{j}
$$

Where $\mathrm{i}$ denotes industry of producer services and $\mathrm{j}$ denotes industry of manufacturing. $y_{i j}$ is the number of producer services purchased from abroad by the manufacturing sector and $y_{\tilde{f}}$ is the output of manufacturing sector. $d_{i j}$ can measure the importance of imported producer services to manufacturing production.

Fig. 2 shows the portion of the forward effects of the imported producer services on the manufacturing industry in BRICS economies including the numbers and the variation trend during 1995-2011. Trough Fig.2 we can get some conclusions:

1. The forward influence of the imported producer services on the manufacturing industry in BRICS economies is very small, which is lower than $0.7 \%$. The highest portion is $0.608 \%$ in India in 2006 .

2. The forward effects of the imported producer services on the manufacturing industry is increasing in China and Brazil, which shows that the promoting effect of the imported producer services on manufacturing service is getting stronger. In 1995 the portion is $0.24 \%$ in Brazil, it increased to $0.459 \%$ in 2011 , It almost the double of the portion in 1995 .

3. The forward influence of the imported producer services on the manufacturing industry after a period of growth began to decline in India. This is because India's domestic service industry after a period of development has reached a relative high level. So the demand for producer services is decline.

4. In Russia the forward influence of the imported producer services on the manufacturing industry is the lowest in four countries, it is $0.245 \%$. 


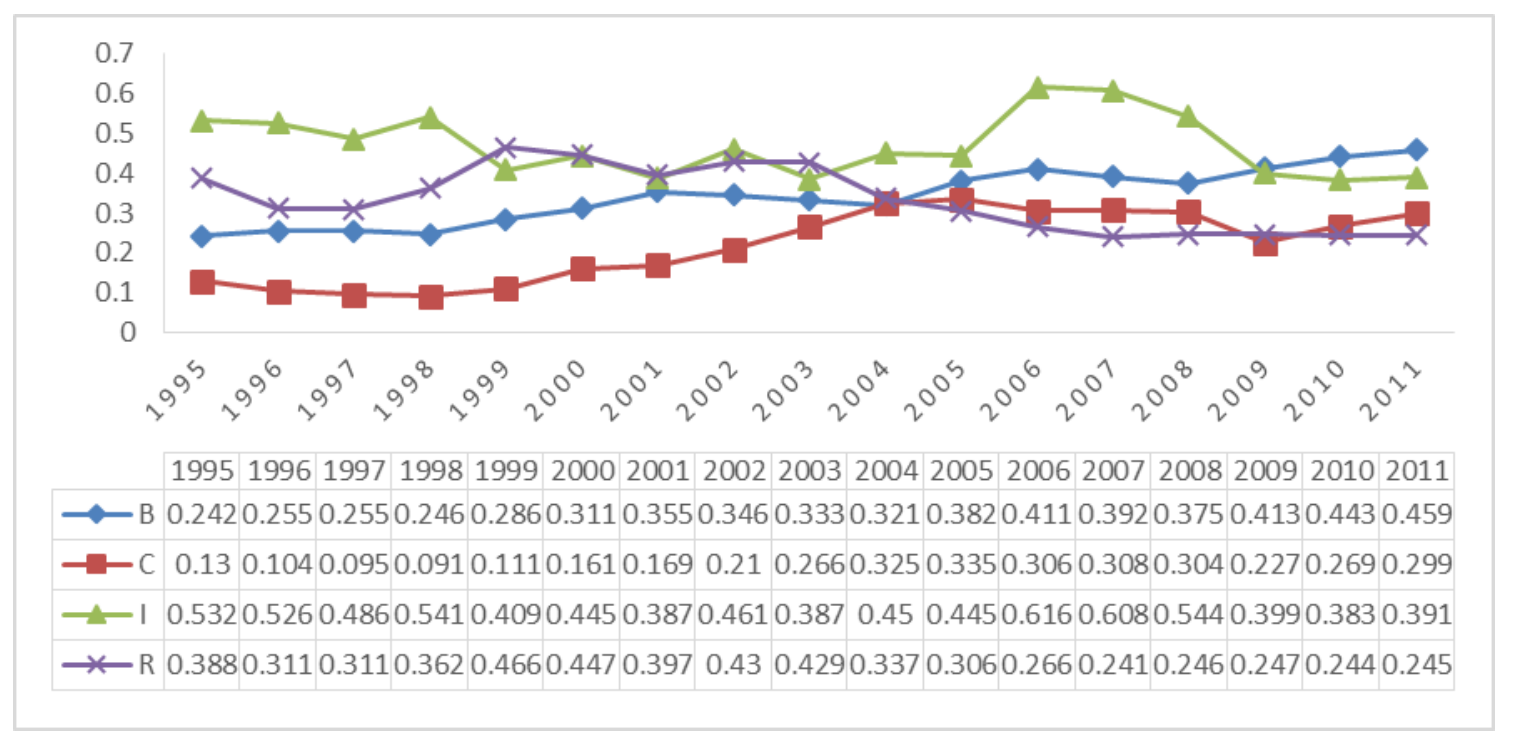

Figure 2. The Forward Effects of Imported Producer Services to Manufacturing .Unit:\%

\section{Backward Effects}

The proportion of imported producer services used by the manufacturing sector in all imported producer services is called the backward effects. It can be described as:

$$
c_{i j}=z_{i j} / z_{j}
$$

Where $\mathrm{i}$ denotes industry of producer services and $\mathrm{j}$ denotes industry of manufacturing. ${ }^{z_{i j}}$ is the number of imported producer services used by the manufacturing sector and $z_{j}$ is the number of imported producer services. $c_{i f j}$ can measure the importance of imported producer services to manufacturing.

Fig. 3 shows the portion of the backward influence of the imported producer services on the manufacturing industry in BRICS economies including the numbers and the variation trend during 1995-2011. Trough Fig.3 we can get some conclusions:

1. China: The backward influence of the imported producer services on the manufacturing industry in China is higher than Brazil and Russia, and it increase to $40.8 \%$ in 2011, while the portion in Brazil is only $15.87 \%$ and in Russia is $18.02 \%$. It means the imported producer services can help China upgrade manufacturing very much. Brazil and Russia should try to purchase more producer services from abroad to try to improve their manufacturing.

2. India: The backward influence of the imported producer services on the manufacturing industry in India is the highest in four countries. It keeps at a high level compared to other three countries, but in 2002 the backward influence is $53.2 \%$, and decreased to $44.9 \%$ in 2011, It means less portion of imported producer services is used in the manufacturing part compared to 2002 in India.

3. Brazil: The backward influence of the imported producer services on the manufacturing industry is low and keeps decreasing from $21.7 \%$ to $15.9 \%$. It is lower than China and India. Brazil should encourage manufacturing purchases more producer services from abroad. It also should pay more attention to the import trade of producer services.

4. Russia: The backward influence of the imported producer services on the manufacturing industry is also very low in Russia. It keeps between 16\%-19.9\% during 1995-2011. It has some kind of increase, but It also should encourage manufacturing purchases more producer services from abroad and pay more attention to the import trade of producer services. 


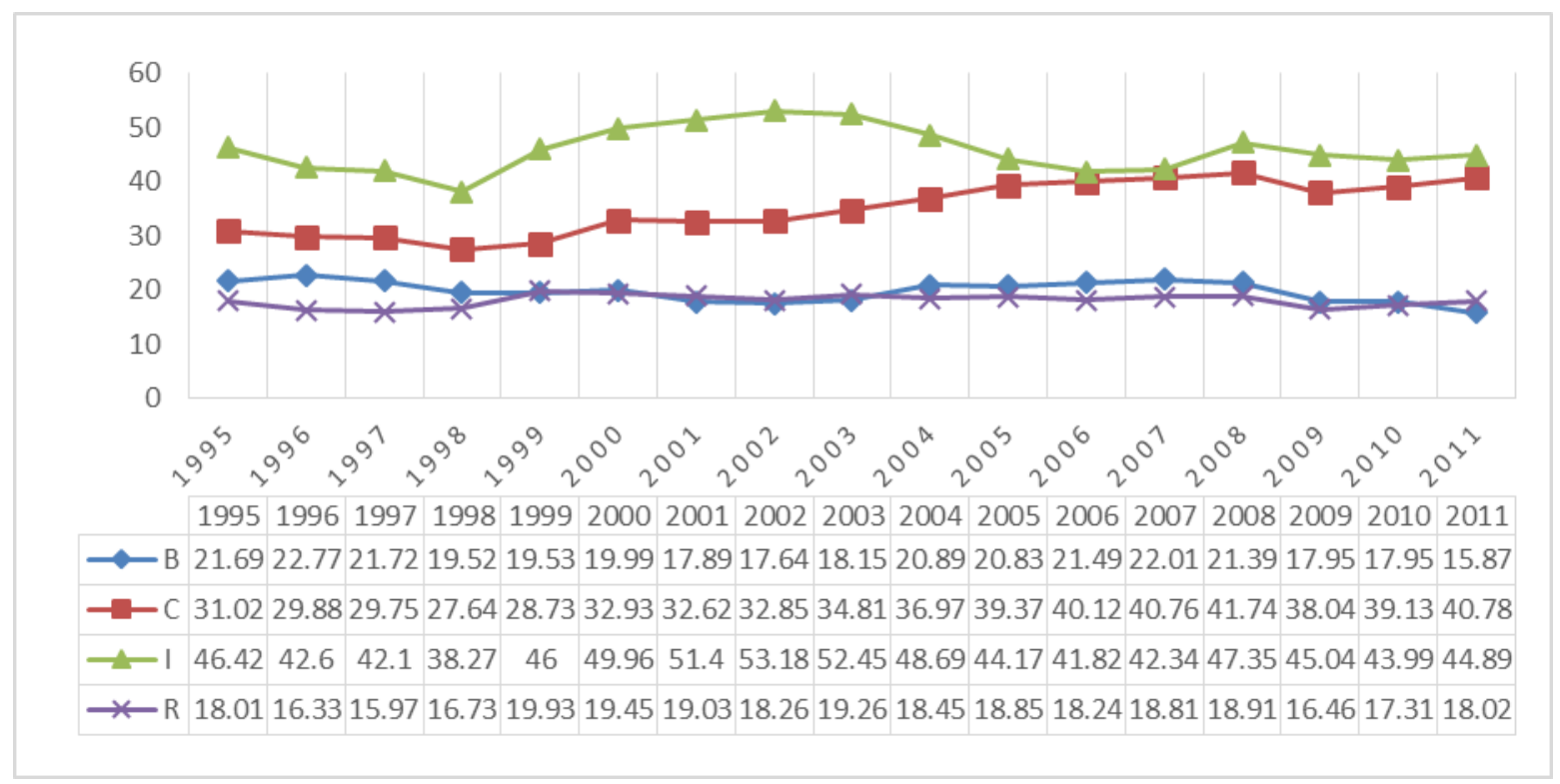

Figure 3. The Backward Effects of Imported Producer Services to Manufacturing. Unit: \%

\section{CONCLUSIONS}

First, the proportion of imported producer services industry in the BRICS economies is above $55 \%$, and there is an increasing trend, which indicates that the attention to the import trade of producer services has been paid in BRICS economies.

Second, the proportion of producer service intermediate inputs in the manufacturing industry is very low, which indicates the BRICS economies has not made full use of the imported producer services in the process of manufacturing upgrade.

At last, the imported producer services have great backward influence on manufacturing industry, but the proportion is less than $50 \%$. That means more than half of imported producer services have not been put into the manufacturing. The manufacturing has not taken full use of imported producer services.

\section{REFERENCES}

[1] Vandermerwe S, Rara J. Servitization of business: adding value by adding services [J]. European Management Journal, 1988, 6 (4) : $314 \sim 324$
[2] James R.Markusen. Trade in Producer Services and in other Specialized Intermediate Inputs [J] The American Economic Review, 1989(3): 46-65.

[3] Joseph François, Julia Woerz. Producer Services, Manufacturing Linkages and Trade [R]. Tin Institute Discussion Paper, 2007-0452

[4] Arnold.J, Javorcik.B.S, Mattoo.A. Does services liberalization benefit manufacturing [R] CEPR Discussion, 2006

[5] Herbert Grubel, Michael Walker.Service industry: cause and effects. [J]. Fraser Institute, 1989(12): 279.

[6] Reetta Elina Kinnunen. Servitization of manufacturing companiesFramework for Analyzing Servitization Capabilities [D]. Department of Information and Service Economy Aalto Universitv School of Economics, 2011

[7] HUANG Qun-hui. The Servitization Intensity of Manufacturing and its Influencing Factors: Based on the World Input-Output Data Analysis [J]. Economic management CASS, 2014, 01: 1-11.

[8] Yang Ling.Imported Producer Services Affects Manufacturing Servitization[J]. Quantitative economic technology and Economic Research,2015,05:37

[9] CHEN Jie xiong. An Empirical Test of the Effect of Manufacturing Service orientation on Corporate Performance A Comparison between Chinese and American Enterprises.Journal of Business Economics.2010, 04: 33-41.

[10] Tang Qiangrong. A Model and Empirical Study of the Symbiotic Development berween the Producer-service Industry and the Manufacturing Industry.Nankai Business Review.2009.03:20-26. 